\title{
Discurso de colação de grau proferido pelo aluno do curso de letras - 2008.2
}

Josimar Alves da Silva ${ }^{1}$

Boa noite a todos!

Saudamos as senhoras, os senhores, amigos, familiares, funcionários, professores, aos coordenadores dos cursos, aos diretores dos Centros, aos Pró-Reitores, ao Magnífico Reitor e em especial a todos os formandos do período 2008.2 da Universidade Federal de Campina Grande do Estado da Paraíba.

Neste momento a alegria invade todo nosso ser, pois estamos concretizando um projeto de nossa vida. Evidentemente que para realizarmos esta caminhada foi necessário batalhar cada dia de nossa vida, cada momento de nossa existência. As dificuldades existiram, mas todas elas foram superadas pelo apoio incondicional da luz de Deus Pai Todo Poderoso que nos encaminhou de forma magistral ao sucesso!

Lembro as palavras do Mestre Jesus Cristo, citada no Evangelho de Mateus no capitulo cinco, versículos 13 e 14 “Vós sóis sal da terra, vós sóis luz do

\footnotetext{
1 Mestrando do Programa de Pós-Graduação em Linguagem e Ensino (UFCG). Graduado Letras pela Universidade Federal de Campina Grande (2008) e em Comunicação Social (DRT № 1417) pela Universidade Estadual da Paraíba (1998). Especialista em Língua Brasileira de Sinais pela FMU (2015). Especialista em Língua Espanhola pela Signorelli (2014). Especialista em Comunicação Educacional pela UEPB (2001). Ator e Diretor (registro no Ministério do Trabalho - DRT № 917). Tem experiência na área de Letras e Jornalismo, atuando principalmente nas seguintes áreas: ensino e formação docente, assessoria de Imprensa, Consultoria em Comunicação e Mestre de Cerimônias, além da área de Artes Cênicas, atuando em teatro, circo, dança e dramaturgia. Atualmente é professor na Escola Estadual de José Pinheiro. É Ator e Diretor do Grupo de Teatro Heureca.
} 
mundo". Sim meus nobres colegas, se refletirmos sobre esta máxima, perceberemos a grandeza desta noite.

Somos o sal da terra, uma vez que, recebemos da Universidade Federal de Campina Grande todo o know-how imprescindível para nos tornarmos cidadãos conscientes e participativos de uma sociedade que clama por homens e mulheres que possam levar seus projetos, suas idéias, suas invenções a todos os brasis.

Somos o sal da terra, porque temos o dever, a obrigação de perpassar o conhecimento que recebemos. Não nos enganemos. A riqueza maior consiste na verdade em partilhar o que temos. As nossas ações boas em cada comunidade, em cada empresa, em cada escola, em cada pedaço de terra que pisarmos serão sementes que se multiplicarão.

Necessitamos e de forma urgente eliminar os preconceitos existentes em nossa esfera terrestre. Preconceitos estes, encontrados na cor, na religião, no sexo, na língua e na cultura. Saibam meus caros que só através da educação poderemos minimizar os absurdos que temos visto em vários setores sociais. E nós somos responsáveis para modificar essa realidade.

A nossa busca constante por uma profissão, nos apresenta hoje como estrelas, como sóis, como vagalumes, como energia pura que nos conecta no tempo e no espaço com a missão de difundir, espalhar, ampliar, todo o nosso potencial para com os nossos semelhantes.

Por isso, nós somos luz do mundo, porque acreditamos que podemos transformar. Toda formação e informação oriunda dos cursos da Universidade Federal de Campina Grande nos elevam nesta noite a um 


\section{Revista Letras Raras}

ISSN: 2317-2347 - Vol. 7, Ano 4, No 2 - 2015

patamar especial: homens e mulheres com um grau, com o poder de conhecimento, que será distribuído para nossa residência, para nosso trabalho, para todos aqueles que desejam um mundo melhor.

Somos luz do mundo, porque nossos interesses são coletivos. Não podemos sob hipótese nenhuma pensar apenas no projeto pessoal.

Nesta perspectiva, devemos combater o egoísmo, a individualidade, a competição desenfreada, a ganância de ter. Porque, meus confrades, somos todos de uma mesma espécie, com os mesmos sentimentos e mais, somos passageiros. E por sermos passageiros, lembremos que alguns colegas não conseguiram terminar esta fase da vida como nós aqui nesta noite. Lembremos que alguns professores também nos deixaram. Só as lembranças permanecem em nossas mentes. Só os sorrisos, as palavras, as imagens.

Somos luz do mundo, porque tivemos o direito a uma educação pública e gratuita.

Quantos jovens estão lá fora se dizimando, se digladiando, suicidandose nas drogas e simplesmente porque não puderam, não quiseram ou não tiveram a força de vontade que todos nós tivemos para chegar neste momento tão sublime e especial.

É claro que as lágrimas muitas vezes rolaram em nossas faces. Até pensamos em desistir, mas lá dentro de nós, no nosso intimo, uma voz cativante sempre surgiu. Você pode!Você é capaz! Se outros conseguiram, você também vai conseguir.

Nós somos luz do mundo, porque temos a missão espinhosa de amenizar as trevas existentes em nosso meio. E que trevas são estas? A 
ignorância, o analfabetismo, o desprezo, o preconceito em geral, a dor, o medo, a vergonha, a ausência da ciência, a imperícia, a falta do saber.

Meus prezados, citando o querido Machado de Assis, no conto Manuscrito de um Sacristão, em que o narrador profere "aplico assim aquela lei de Helvetius: o grau de espírito que nos deleita dá a medida exata do grau de espírito que possuímos." Que possamos aplicar a partir de agora com deleite tudo o que aprendemos com os nossos professores, sem esquecermos que a humildade deve nos acompanhar sempre. Apliquemos nossa força para um ambiente mais saudável. Busquemos a tolerância em nosso cotidiano. Pois o grau que hoje estamos obtendo é fruto de toda uma caminhada.

Amigos, não somos maiores em relação aos pobres, ignorantes, mendigos, e estropiados. Não somos melhores em relação aqueles que largaram a oportunidade de uma formação no nível superior ou que foram obrigados a esquecer o estudo para sobreviver de sub-empregos.

O que somos na verdade? Somos seres em evolução e devemos fazer a nossa parte, assim como esta Universidade fez dando-nos qualificação. É impossível trabalhar pelo próximo? Será necessário ter muito dinheiro?

Jesus não tinha dinheiro, Gandhi não tinha dinheiro, Madre Tereza de Calcutá não tinha dinheiro e Betinho não tinha dinheiro. Todos eles apresentaram a vontade de uma vida melhor para os seus semelhantes. Eles planejaram, traçaram suas metas e conseguiram a realização dos projetos pelo bem comum. E nós? O que estamos esperando? A charrua pertence a cada um. 


\section{Revista Letras Raras}

ISSN: 2317-2347 - Vol. 7, Ano 4, No 2 - 2015

Sejamos, nesta nossa vida tão breve, sal da terra e luz do mundo para aqueles que anseiam por justiça e por igualdade. Deleitemo-nos nosso espírito para a luta constante e assim receberemos todas as benesses.

Portanto, esta é uma noite em que devemos agradecer. Agradecer a Universidade Federal de Campina Grande que nos proporcionou toda a formação. Agradecer aos nossos professores e funcionários que nos deram toda a informação. Agradecer aos amigos, colegas que nos estimularam durante toda nossa jornada. Agradecer aos familiares que contribuíram de forma direta e indireta, para que este dia fosse realidade em nossas vidas. Agradecer a Deus pela oportunidade de elevarmos nosso espírito.

Parabéns a todos nós.

Muito obrigado! 